\title{
Muuntogeenisen ja tavanomaisesti jalostetun perunan rinnakkaisviljely - kustannukset ja niiden kohdentuminen
}

Jussi Tuomisto, MTT Taloustutkimus.Luutnantintie 1300410 HELSINKI jussi.tuomisto@mtt.fi

Tiivistelmä: Tämän tutkimuksen tarkoituksena on arvioida KTTK:n tarkastusaineiston ja tilamallilaskelmien avulla, mitä kustannuksia aiheutuu muuntogeenisen ja tavanomaisten perunalajikkeiden erilläänpidosta tilatasolla ja mille osapuolelle kustannukset kohdistuvat. Tutkimus arvioi myös, millainen tulee olemaan sopimustuotannon rooli lajikkeiden erilläänpidon varmistamiseksi. Rinnakkaisviljely on kallis toteuttaa. Mitä tiukemmat erilläänpitovaatimukset ovat, sitä korkeammaksi kustannukset nousevat. Kustannuksia kohdentuu myös muille kuin muuntogeenisiä lajikkeita tuottaville viljelijöille. Yhden välivuoden vaatimus siirryttäessä gm-perunasta tavanomaisen perunan viljelyyn nostaa perunan tuotantokustannusta 8,58 senttiä/kg. Viljelijän aloittaessa muuntogeenisten perunalajikkeiden viljely, hänen ei ole enää taloudellisesti kannattavaa palata samoilla lohkoilla tavanomaisten perunalajikkeiden viljelyyn. 10 metrin suojakaistavaatimus perunalohkojen, jossa viljellään gm- ja tavanomaista perunaa, välille nostaa perunan tuotantokustannuksia 2,34 senttiä/kg. Kustannusten noustessa sekä gm- että tavanomaisen perunan ja perunatuotteiden tuontipaine ulkomailta lisääntyy. Ongelmallisinta rinnakkaisviljelyn toteuttamisen suhteen on viljely kotitarvepalstoilla sekä maatilojen oman siemenlisäyksen toteuttaminen. Ongelmana on myös lajittelujätteen käsittely ja markkinointi. Ongelmat saattavat johtaa peitellyn toiminnan (moral hazard problem) esiintymiseen. Geenitekniikan käyttöönotto lisää tarjontaketjun verkottumista: gm-siemen tulee markkinoille lajike-edustajien kautta. Perunalajikkeiden jalostaja kerää osan hyödystä itselleen ketjujen kautta. Mitä tiukemmat ovat gm-vapaan perunan lajikesekaannusrajat, sitä enemmän lajike-edustaja kykenee hyötymään suhteessa viljelijään. Gm-perunan täytyy kuitenkin hyödyttää myös viljelijää, muuten viljelijät eivät ota gm-lajikkeita viljelykseen.

Asiasanat: geenitekniikka, peruna, rinnakkaisviljely, tarjontaketju, sopimustuotanto, vertikaalinen koordinaatio, kannattavuus, kannattavuuskerroin. 


\section{Johdanto}

EU:n komission on antanut suosituksen jäsenmaille ohjeista kansallisten strategioiden ja parhaiden käytänteiden laatimiseksi eri tuotantomuotojen rinnakkaiseloa varten viljeltäessä muuntogeenisiä viljelykasveja sekä tavanomaisia tai luonnonmukaisesti tuotettavia lajikkeita. Jotta Euroopan kuluttajilla olisi todellinen mahdollisuus valita eri tavalla tuotettujen elintarvikkeiden välillä, eivät lainsäädännön uudet jäljitettävyys- ja merkintävaatimukset yksistään riitä, vaan maatalouden on myös tuotettava erilaisia ja eri tavalla tuotettuja hyödykkeitä. Rinnakkaiselo liittyy siihen, voivatko maanviljelijät tuottaa tavanomaisia viljelykasveja, luonnonmukaisesti tuotettuja ja muuntogeenisiä viljelykasveja tuotannon välillä noudattamalla merkintöjä ja tai puhtautta koskevia lainsäädännöllisiä vaatimuksia. Pyrkimyksenä on, etteivät kynnysarvot ylittyisi niissä tuotteissa, jotka eivät muutoin edellyttäisi gm-merkintää. Rinnakkaiselon yhtenä yleisperiaatteena on komission suosituksen mukaan oltava, että sen, joka tuo uuden tuotantotavan jollekin alueelle, on huolehdittava niistä viljelytoimenpiteistä, jotka ovat alueella tarpeen geenivirran rajoittamiseksi. Yksi keskeisimmistä kysymyksistä on lajikkeiden tai lajien risteytyminen keskenään (Angevin et al. 2002). Toinen keskeinen tekijä on siementen sekoittumisesta tai jääntikasveista aiheutuva lajikepuhtauden väheneminen viljelyn yhteydessä.

Muuntogeenisiä kasveja tulee Suomessa viljeltäväksi todennäköisesti vuoteen 2010-2012 mennessä (Rikkonen 2005). Perunaa lukuun ottamatta keskieurooppalaiset muuntogeeniset viljelykasvit eivät useimmiten sovellu viljelyyn Suomessa ilman jatkojalostusta (Tuomisto 2004). Siksi on todennäköisintä, että peruna tulee olemaan ensimmäinen geenimuunneltu viljelykasvi, joka tullaan Suomessa ottamaan viljelykäytäntöön (Tuomisto 2005).

2.11.2005 antoi Maa- ja metsätalousministeriön asettama muuntogeenisten viljelykasvien sekä tavanomaisten ja luonnonmukaisen maataloustuotannon rinnakkaiseloa miettinyt työryhmä väliraportin, jonka mukaan muuntogeenisen aineksen leviämisen estämiseksi (MMM 2005):

1. jos käytetään TOS-siemenperunaa, se on kasvatettava lohkoilla, joissa ei ole tuotettu muuntogeenistä perunaa, kun halutaan muuntogeenisestä aineksesta täysin vapaata siemenperunaa.

2. työkoneet puhdistettava erityisen huolellisesti, kun ne ovat yhteiskäytössä ja alueilla, joilla viljellään muuntogeenistä perunaa.

3. määritettävä eristysetäisyydet (5 - $10 \mathrm{~m})$.

4. kerättävä ja hävitettävä jääntikasvit.

5. muokattava maa sadonkorjuun jälkeen siten, että jääntimukulat nousevat maan pintaan.

6. kauppakunnostuksen ja lajittelun erotemukuloita on käsiteltävä asianmukaisesti siten, että lajikkeiden välistä sekaantumista voidaan estää.

7. gm-perunan jälkeen saa lohkolla viljellä ei-gm-perunaa vasta 2 vuoden kuluttua ja siemenenä on tällöin käytettävä sertifioitua siemenperunaa.

8. valvontatoimenpiteiden oltava riittäviä, ja ne on kohdistettava oikein.

Tämän tutkimuksen tarkoituksena on selvittää, mitä taloudellisia vaikutuksia rinnakkaiselon toteuttamisen eri toimenpiteet tulisivat maksamaan tilatasolla suomalaisessa ruokaperunantuotannossa.

\section{Aineisto ja menetelmät}

Suomessa Kasvintuotannon tarkastuskeskuksen (KTTK) siementarkastusosasto (STO) tarkastaa kaikki siemenperunaviljelykset. Ruokaperuna- ja tärkkelysperunaviljelyksiä tarkastetaan ainoastaan pistokokein vaarallisten kasvitautien osalta. Siemenperunantuotannon viljelytarkastukset kuitenkin antavat viitteitä siitä kuinka paljon vieraita lajikkeita perunalohkoilta on kasvustotarkastuksissa löytynyt ja mitkä tekijät ovat aiheuttaneet väärien lajikkeiden esiintymistä perunalohkoilla. Huomioiduksi tulevat tällöin muun muassa eristysetäisyydet sellaisille lohkoille joissa viljellään toista lajiketta ja kuinka viljelykierto on vaikuttanut maahan jääneiden mukuloiden säilymiseen itämiskykyisinä. Taulukossa 1 on esitetty KTTK:n viljelystarkastusaineisto vuosilta 1998-2004.

Vuosina 1998-2003 Kasvintuotannon tarkastuskeskus tarkasti 2524 siemenperunanviljelystä, yhteensä 9203 hehtaaria. Tarkastettavia mukuloita kerättiin tältä alalta 315500 kappaletta. Vieraita lajikkeita näistä löytyi $256^{1}$ mukulaa, eli 0,08 prosenttia tarkastetuista. Ainoastaan yhdellä siemen-

\footnotetext{
${ }^{1}$ Yhdeltä maatilalta löydettiin 180 kappaletta vääriä lajikkeita (Outlier-onglma). Kyseinen siemenperunatila oli perussiementä tuottava tila, joten se on myös huomioitava vertailtaessa väärien lajikkeiden löytymistä perussiementä ja sertifioitua siementä tuottavilla tiloilla.
} 
perunaviljelyksellä oli vieraita lajikkeita kasvustossa enemmän kuin 0,9 prosenttia ${ }^{2}$. Viljelyksiä, joista löytyi vieraita lajikkeita, oli 50, eli 1,98 prosenttia viljelystarkastetuista. Näistä kymmenellä oli ollut perunaa edellisenä vuotena samalla lohkolla ja 35:llä oli ollut perunaa samalla lohkolla 3 vuotta aikaisemmin, jolloin oli ollut jotain muuta kasvia viljelyksessä kahtena vuotena. Kolmen vuoden takaisista perunanviljelyksistä ei muodostunut enää talvehtineiden perunoiden ongelmaa.

Taulukko 1. KTTK:n viljelystarkastusaineiston yhteenveto vuosilta 1998-2004 (Lähde KTTK 2005):

Tutkimusaineisto

Tutkimusala (hehtaaria)

Testattuja lohkoja (kappaletta)

Tutkittujen mukuloiden määrä (kpl)
Kaikki siemenperuna

9203

2524

315500
Perussiemen

153125

Tulokset

Vieraita lajikkeita (kpl)

\% kokonaismäärästä

$0,08 \%$

$0,15 \%$

poislukien outlier (yhdellä tilalla 180 kpl vääriä lajikkeita)

76

53

\% kokonaismäärästä (Ilman outlier-tapausta)

$0,02 \%$

$0,03 \%$

Niiden lohkojen lukumäärä, joilta löytyi vieraita lajikkeita (kpl)

50

37

\% lohkojen kokonaismäärästä

$1,98 \%$

$3,02 \%$

joista perunaa oli viljelty edellisenä vuonna (sama lajike) (kpl)

10

2

\% niiden lohkojen lukumäärästä, joista löytyi vääriä lajikkeita

$20,00 \%$

$5,41 \%$

\% kaikkien lohkojen kokonaismäärästä

joista perunaa oli viljelty kolme vuotta aikaisemmin

(mahdollisesti eri lajike) (kpl)

$0,40 \%$

$0,16 \%$

\% niiden lohkojen lukumäärästä, joista löytyi vääriä lajikkeita

\% kaikkien lohkojen kokonaismäärästä

35

31

$70,00 \%$

$83,78 \%$

$1,39 \%$

$2,53 \%$

Keskimääräinen viljelyetäisyys (metriä)

56,7

25,1

Niiden lohkojen keskimääräinen viljelyetäisyys, joilta oli löytynyt

vääriä lajikkeita (metriä)

8,9

5,1

Keskimääräinen lohkokoko

Niiden lohkojen keskikoko, joilta oli löytynyt vääriä lajikkeita (ha)

Keskimääräinen viljelyetäisyys perunanviljelyksissä oli 57,6 metriä. Niillä lohkoilla, joilta vääriä lajikkeita löytyi, keskietäisyys oli 8,9 metriä. Näistä 74 prosentilla etäisyys toiseen perunaviljelmään oli alle 3 metriä. Tutkimuksissa on havaittu, että muuntogeenisten perunalajikkeiden viljelykseltä ei leviä siitepölyä muihin perunoihin, jotka ovat kasvaneet 20 metrin etäisyydellä (Tynan ym. 1990, McPartlan \& Dale 1994, Connor \& Dale 1996). Myöskään risteytyminen perunan luonnonvaraisten sukulaisten kanssa ei ole yrityksistä huolimatta onnistunut (Eijlander \& Stiekema 1994). On todennäköistä, että lajikesekaantumisia saattoi tapahtua lajikkeiden fyysisenä siirtymisenä lohkolta toiselle esimerkiksi sadonkorjuun yhteydessä. Tutkimusaineiston mukaan mukuloiden fyysistä siirtymistä lohkolta toiselle havaittiin vain, kun lohkojen etäisyydet ovat alle 3 metriä. Myös lohkojen koko näytti vaikuttavan lajikesekaannukseen. Kaikkien vuosina 1998-2003 viljelystarkastettujen

\footnotetext{
${ }^{2}$ EU:n kynnysarvo on, että tuotteessa, joka on ilmoitettu vapaaksi geenimuunnelluista ainesosista, saa olla enintään 0,9 prosenttia geenimuokattua ainesta.
} 
siemenperunalohkojen keskikoko oli 3,65 hehtaaria. Niiltä viljelyksiltä, joilla vääriä lajikkeita löytyi, keskikoko oli 1,81 hehtaaria. Perunan talvehtiminen, lohkojen koot ja lohkojen etäisyydet vaikuttavat voimakkaimmin lajikesekaannuksiin.

Vuosina 1998-2004 KTTK tarkasti siemenperunan varastotarkastuksina 153,8 miljoonaa kiloa siemenperunaa. Tarkastettavia mukuloita kerättiin yhteensä 2,6 miljoonaa kappaletta tarkastettavien mukuloiden paino oli 147 tonnia, eli 0,096 \% kokonaismäärästä. Tarkastuksissa löytyi ainoastaan 9 kappaletta väärää lajiketta $(0,0001 \%)$. Johtopäätös on, että varasto- ja lajikesekaannuksia ei käytännössä ollut tai tarkastajat eivät kyenneet erottamaan vääriä lajikkeita.

Tässä tutkimuksessa taloudellisia vaikutuksia on arvioitu tilamallilaskelmilla ja aikaisempien taloustutkimusten tuloksilla (mm. Tuomisto 2005, Tuomisto 2004, Tuomisto 2003, Turunen 2001, Tuomisto ja Antila 2001). Tilamallilaskelmat ovat tuotantokustannus- ja nettovoittolaskelmia. Laskelmien avulla on arvioitu, mitä taloudellisia vaikutuksia rinnakkaiselon eri toimenpiteet tulisi maksamaan tilatasolla suomalaisessa ruokaperunantuotannossa.

\section{Tulokset ja tulosten tarkastelu}

GM- ja tavanomaisen siemenperunan erilläänpito voidaan toteuttaa nykyisillä viljelykierrolla ja nykyisellä tarkastustoiminnalla. 0,3 \%:n kynnysarvo riittää siemenperunalle, koska nykyisinkin vääriä lajikkeita saa sertifioidulla siemenperunalla olla enintään $0,2 \%$ ja perussiemenellä $0,1 \%$. (MMM:n asetus siemenperunakaupasta 112/2000, muutettu asetuksella 22/01).

Ruokaperunantuotannossa ongelmana on monokulttuuri ja viljelyn keskittyminen suppealle alueelle, vaikka todettakoon, että siemenperunantuotanto on alueellisesti vielä keskittyneempää (Tuomisto 2004, Virolainen 2001, Niemi et al. 2003). Ruokaperunan tuotantokustannus on 25,93 senttiä/kg (vaihteluväli 25,21-30,31 senttiä/kg) monokulttuurissa, kun lisäyssiemen tuotetaan itse omalla tilalla. Liitteessä 1 on esitettynä eri toimenpidevaatimusten vaikutus ruokaperunantuotannon tuotantokustannuksiin ja kannattavuuteen.

\section{Välivuosivaatimus}

Yhdenkin välivuoden vaatimus silloin kun siirrytään gm-perunasta tavanomaisen (ei-gm) perunan viljelyyn, muuttaa siirtymävuonna viljelyn kannattamattomaksi keskikokoisella päätoimisella 37,50 hehtaarin maatilalla. Yksi välivuosi, jolloin lohkolla viljellään viljaa, nostaa ruokaperunan tuotantokustannusta 8,58 senttiä (24,9 \%) (vaihteluväli 25,21-30,31 senttiä/kg) monokulttuurissa, kun perunan lisäyssiemen viljellään itse. Jos viljelijä viljelee gm-perunaa ja sen jälkeen siirtyy tavanomaisen perunan viljelyyn, yhden välivuoden jälkeen, jonka aikana viljelijä on lohkolla viljellyt viljaa, ruokaperunan tuotantokustannus on ensimmäisenä perunanviljelyvuotena 8,58 senttiä korkeampi kuin ilman välivuotta. Kaksi välivuotta nostaa ruokaperunan tuotantokustannusta 16,72 senttiä/kg (39,2 \%) (vaihteluväli 8,77-22,46 senttiä/kg).

Välivuosivaatimus vaikeuttaa viljelijän siirtymistä gm-perunan viljelystä tavanomaisen (ei-gm) perunan viljelyyn, koska ensimmäisen tavanomaisen perunan viljelyvuoden tuotantokustannus nousee liian korkeaksi. Tämä parantaa gm-perunaa tuottavan kilpailuetua. Toisaalta tietoisuus ns. uponneista kustannuksista ja epävarmuudesta (tai riskistä) aiheutuvista kustannuksista saattaa estää viljelijää siirtymästä gm-perunan viljelyyn.

\section{Suojakaistavaatimus}

Laskelman oletuksena on, että perunaa viljellään päätuotantosuunatana, lohkon koko on kolme hehtaaria, suojakaista on lohkon jokaisella reunalla (perunaa viljellään perunanviljelykseen keskittyneellä alueella), lohko on neliön muotoinen ja suojakaistalla viljellään viljaa, joka korjataan.

Jos suojakaistavaatimus on 10 metriä, suojakaistan ala on kolmen hehtaarin lohkossa 0,69 hehtaaria, (23 prosenttia kasvulohkon koosta), se nostaa ruokaperunan tuotantokustannusta 2,34 senttiä/peruna-kg (vaihteluväli 1,41-3,60 senttiä/kg) eli 9 prosenttia. Viiden metrin suojakaista nostaa ruokaperunan tuotantokustannusta 0,98 senttiä/peruna-kg (vaihteluväli $0,61-1,71$ senttiä/kg) eli 3,6 prosenttia. Mikäli suojakaistavaatimus asetetaan viljelijälle, joka viljelee gm-perunaa, kohdentuvat kustannukset gm-perunaa tuottavalle. Tämä asettaa parantaa tavanomaista perunaa (ei-gm) viljelevän kilpailuetua. Kuviossa 1 ja liitteessä 1 on esitetty suojakaistan vaikutus perunantuotannon tuotantokustannukseen. 


\section{Muokkaus sadonkorjuun jälkeen}

Kevyellä äestyksellä (joustopiikkiäkeellä) voidaan perunan sadonkorjuun jälkeen nostaa maahan jääneet mukulat pintaan niin, että ne jäätyisivät talvella, eivätkä olisi itämiskykyisiä seuraavana kasvukautena ${ }^{3}$. Kevyt äestys nostaa ruokaperunan tuotantokustannusta 0,02 senttiä/kg (0,1\%). Kevyt äestys on halvin keino vähentää vieraiden lajikkeiden määrää seuraavana kasvukautena.

\section{Sertifioidun siemenen käyttövelvoite}

Sertifioidun siemenen käyttövelvoite ei lisää ruokaperunantuotannon tuotantokustannusta. Tällöin oletetaan, että lisäyssiementuotannosta vapautuva ala kasvattaa myytävän perunan tuotantoalaa 10 prosenttia. Lisäksi viljelijä voi saada koko peruna-alalle korkeamman, sopimustuotannon mukaisen perunantuotannon kansallisen tuen. Laskelmissa ei ole tällöin huomioitu, että mahdollisesti ruokaperunantuottajat käyttävät (sääntöjen vastaisesti) ruokaperunaa siemenenä silloin kun ruokaperunasta on ylituotantoa.

\section{Kuvio 1. Suojakaistasta aiheutuva lisäkustannus senttiä/peruna-kg}

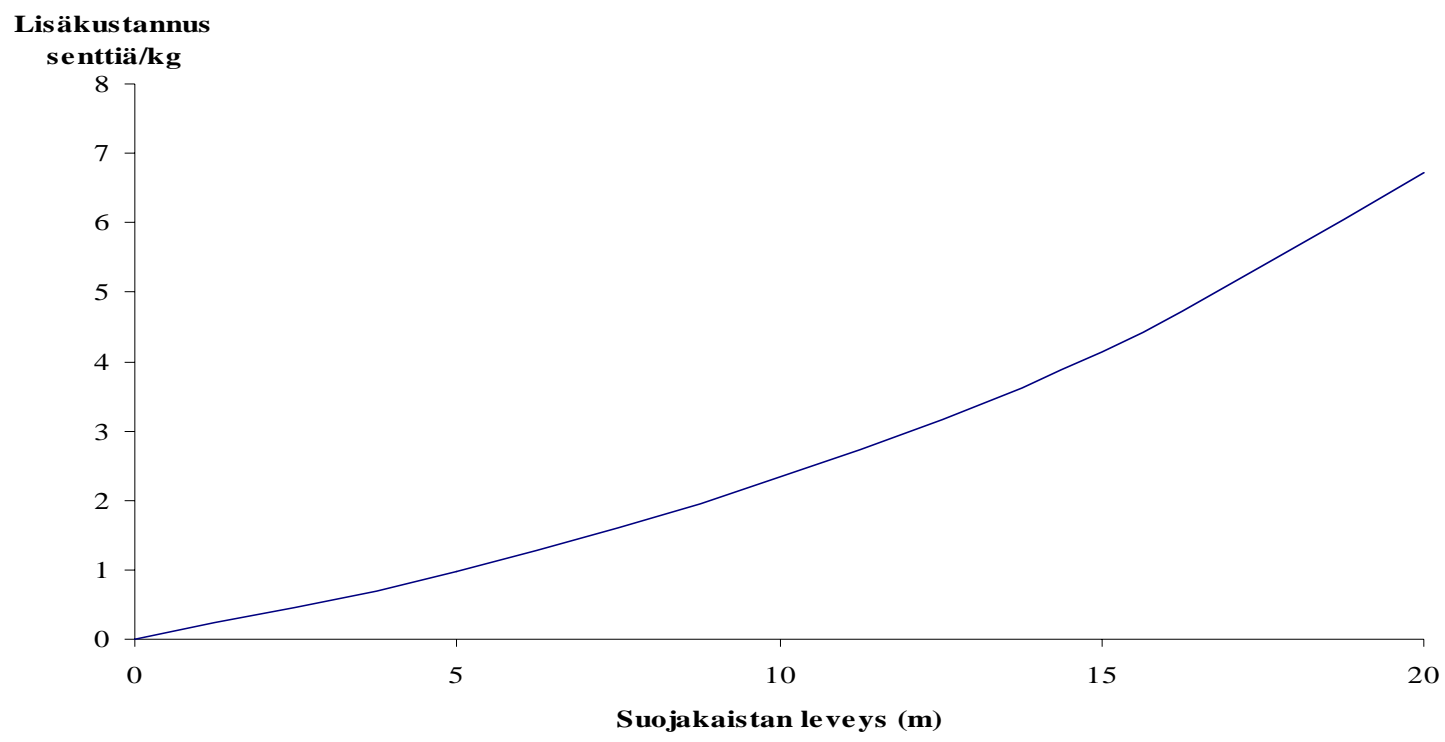

\section{Johtopäätökset}

Kahden vuoden karenssi gm-perunan jälkeen on kallis toteuttaa. Viljelijän aloittaessa gm-perunan viljely, ei olisi taloudellisesti kannattavaa enää palata samoilla lohkoilla tavanomaisen perunan viljelyyn. Se antaisi kilpailuedun gm-perunalle. Yhden vuoden karenssilla saavutetaan lähes sama tulos huomattavasti edullisemmin kustannuksin.

10 metrin suojakaista on liian kallis toteuttaa ja se alentaa gm-perunan kilpailukykyä suhteessa tavanomaiseen perunaan (jos suojakaistavaatimus on asetettu gm-perunaa tuottavalle). Viiden metrin suojakaistalla saavutetaan lähes sama tulos huomattavasti alhaisemmin kustannuksin. Tutkimuksen mukaan lajikesekaannuksista 74 prosenttia oli lohkoilla, joilla etäisyys oli alle kolme metriä.

Perunapellon äestys joustopiikkiäkeellä sadonkorjuun jälkeen on halpa keino vähentää perunan talvehtimista ja vieraiden lajikkeiden esiintymistä seuraavana kasvukautena.

Perunan tuonti Ruotsista aiheuttaa 1,5-3,3 senttiä/kg kustannuslisän. Mitä tiukemmaksi viljelyrajoitteet rinnakkaiselovaatimusten toteuttamiseksi asetetaan, sitä korkeammaksi kustannukset nousevat ja sitä enemmän tuontiperuna tai tuontiperunatuotteet (myös geenimuokatut) saavat kilpailuetua. Tuontipaineet lisääntyvät varsinkin valmistuotteissa.

Ongelmallisinta rinnakkaisviljelyn toteuttamisen suhteen on viljely kotitarvepalstoilla sekä maatilojen oman siemenlisäyksen (TOS-siemen) toteuttaminen. Ongelmana on myös lajittelujätteen käsittely ja markkinointi. Ongelmat saattavat johtaa peitellyn toiminnan (moral hazard problem) esiintymiseen. Yhteiskunnan on vaikea valvoa, toimiiko viljelijä kaikissa tapauksissa sääntöjen mukaisesti. Näin voi tapahtua muun muassa perunan myynnissä suoraan tilalta.

\footnotetext{
${ }^{3}$ Lähde: Kuisma, P. 2005. Puhelinhaastattelu 24.5.2005. Paavo Kuisma. Perunantutkimuslaitos.
} 
Geenitekniikan käyttöönotto lisää tarjontaketjun verkottumista: gm-siemen tulee markkinoille lajike-edustajien kautta. Perunalajikkeiden jalostaja kerää osan hyödystä itselleen ketjujen kautta. Mitä tiukemmat ovat gm-vapaan perunan lajikesekaannusrajat, sitä enemmän lajike-edustaja kykenee hyötymään suhteessa viljelijään: viljelijän on vaikeampi siirtyä takaisin gm-perunan tuotannosta tavanomaisten lajikkeiden tuotantoon, kun lajikesekaannusrajat ovat korkeat. Gm-perunan täytyy kuitenkin hyödyttää myös viljelijää, muuten viljelijät eivät ota gm-lajikkeita viljelykseen.

\section{Kirjallisuus}

Angevin, F., Colbach, N., Meynard, J.-M., Roturier C., Sweet J., Philp A., Menrad, K., Menrad, M. Wörner S., Kilpatrick J., Bonfini, L., Van den Eede, G. 2002. Scenarios for co-existence of genetically modified, conventional and organic crops in European agriculture. A synthesis report. prepared by Anne-Katrin Bock. IPTS, Institute for Prospective Technological Studies. European Comission Joint Research Centre. 66 p.

Connor, A.J. \&, Dale, A.J. 1996. Reconsideration of pollen dispersal data from field trials of transgenic potatoes. Theor. Appl. Genet. 92: 505-508.

Eijlander, R., \& Stiekema, W.J. 1994. Biological containment of potato (Solanum tuberosum): Outcrossing to the related wild species black nightshade (Solanum nigrum) and bittersweet (Solanum dulcamara). Sex Plant Reprod 7: 29-40.

KTTK 2005. Siemenperunan viljelystarkastukset 1998-2004. Kasvintuotannon tarkastuskeskus (KTTK).

McPartlan, H.C. \& Dale, P.J. 1994. An assessment of gene transfer by pollen from field grown transgenic potatoes to non-transgenic potatoes and related species. Transg. Res. 3: 216-225.

MMM 2005. Muuntogeenisten viljelykasvien sekä tavanomaisen ja luonnonmukaisen maataloustuotannon rinnakkaiselon mahdollistaminen Suomessa. Loppuraportti (luonnos 2.11.2005)

Niemi, J., Mäkelä, S. \& Tuomisto, J. 2003. The Distribution of Costs and Benefits from the Commercial Introduction of Genetically Modified Crops: A Case Study on Potato in Finland. A paper presented at the 7th ICABR Conference in Ravello, Italy, June 29 to July 3, 2003.

Rikkonen, P. 2005. Utilisation of alternative scenario approaches in defining the policy agenda for future agriculture in Finland. Agrifood Research Reports 73: 223 p., 8 appendices. (Doctoral Dissertation).

Turunen, H. 2001. Perunantuotannon tilamallit. (Farm models on potato production) Maa- ja elintarviketalouden tutkimuskeskuksen (MTT) taloustutkimuksen (MTTL) selvityksiä 23/2001. 62 p. Helsinki.

Tuomisto, J. 2003. Siemenperunan sopimustuotanto Suomessa. Sopimustuotanto siemenperunan markkinaepävarmuudesta aiheutuvan hyvinvointitappion alentajana. MTT, Maa- ja elintarviketalous 22, 109 s.

Tuomisto, J. 2004. Benefits and costs of the first wave of gene technology: A case study on potato in Finland. A paper presented at the 8 th ICABR International Conference on Agricultural Biotechnology: International Trade and Domestic Production Ravello (Italy), July 8 - 11, 2004. 19 p.

Tuomisto, J. 2005. Co-existence of GM and non-GM potato varieties on Finnish potato farms - potential costs and remedies. A paper presented at the 9 th ICABR International Conference on Agricultural Biotechnology: International Trade and Domestic Production Ravello (Italy), July 7 - 12, 2005. 21 p.

Tuomisto, J. ja Antila E. 2001. Tärkkelysperunan kannattavuusvertailu tilamallien avulla. Tärkkelysperunantuotannon käsikirja 17.10.2001 Seinäjoki.

Tynan, JL., Williams, MK., Conner, AJ., 1990. Low frequency of pollen dispersal from a field trial of transgenic potatoes. J. Genet. \& Breed. 44: 303-306.

Virolainen, M. 2001. Geenitekniikan omaksumisen taloudelliset vaikutukset Suomen elintarvikeketjussa. Casetutkimukset rypsistä ja perunasta. MTT taloustutkimuksen (MTTL) selvityksiä 19/2001. Helsinki: MTT taloustutkimus. $49 \mathrm{~s}$. 
Liite 1. Nettovoittolaskelma GM- ja ei-GM-perunan rinnakkaisviljelystä aiheutuvista kustannuksista keskikokoisella suomalaisella päätoimisella ruokaperunatilalla (37,50 ha)

\begin{tabular}{|c|c|c|c|c|c|c|c|c|c|c|c|c|c|c|c|c|c|}
\hline & \multicolumn{2}{|c|}{ Monokulttuuri } & \multicolumn{5}{|c|}{ Pakollinen viljelykierto } & \multicolumn{4}{|c|}{ Pakolliset suojakaistat } & \multirow[b]{2}{*}{$\begin{array}{l}\text { Erilli- } \\
\text { nen } \\
\text { varasto } \\
\text { GM- } \\
\text { tuot- } \\
\text { teelle } \\
(50 / 50) \\
\end{array}$} & \multirow[b]{2}{*}{$\begin{array}{l}\text { Ylimää } \\
\text { räinen } \\
\text { puhdis- } \\
\text { tus }\end{array}$} & \multirow[b]{2}{*}{$\begin{array}{l}\text { Ylimää } \\
\text { räinen } \\
\text { äestys } \\
\text { syk- } \\
\text { syllä } \\
\end{array}$} & \multicolumn{3}{|c|}{$\begin{array}{l}\text { Ylimääräiset tarkastukset } \\
\text { (KTTK) }\end{array}$} \\
\hline & \begin{tabular}{|l} 
Ei \\
viljaa \\
\end{tabular} & $\begin{array}{l}\text { Ei } \\
\text { viljaa, } \\
100 \% \\
\text { serti- } \\
\text { fioitu } \\
\text { siemen } \\
\end{array}$ & $\begin{array}{l}50 \% \\
\text { viljaa } \\
\end{array}$ & $\begin{array}{l}1 / 3 \\
\text { viljaa }\end{array}$ & $\begin{array}{l}2 / 3 \\
\text { viljaa }\end{array}$ & $\begin{array}{l}50 \% \\
\text { kesan- } \\
\text { toa } \\
\end{array}$ & $\begin{array}{l}1 / 3 \\
\text { kesan- } \\
\text { toa, } 1 / 3 \\
\text { viljaa } \\
\text { ja } 1 / 3 \\
\text { perunaa } \\
\end{array}$ & $\begin{array}{l}20 \\
\text { metrin } \\
\text { suoja- } \\
\text { kaista } \\
\end{array}$ & $\begin{array}{l}15 \\
\text { metrin } \\
\text { suoja- } \\
\text { kaista } \\
\end{array}$ & $\begin{array}{l}10 \\
\text { metrin } \\
\text { suoja- } \\
\text { kaista } \\
\end{array}$ & $\begin{array}{l}5 \\
\text { metrin } \\
\text { suoja- } \\
\text { kaista } \\
\end{array}$ & & & & $\begin{array}{l}\text { Labora- } \\
\text { torio- } \\
\text { tarkas- } \\
\text { tus } \\
\end{array}$ & $\begin{array}{l}\text { Kasvus } \\
\text { to- } \\
\text { tarkas- } \\
\text { tus } \\
\end{array}$ & $\begin{array}{l}\text { Kaup- } \\
\text { pa- } \\
\text { kunnos- } \\
\text { tus- } \\
\text { tarkas- } \\
\text { tus } \\
\end{array}$ \\
\hline - Tarvikekustannus & 100271 & 114658 & 50427 & 67067 & 33768 & 50336 & 33707 & 54409 & 65801 & 77292 & 88882 & 80656 & 80418 & 100312 & 80418 & 80418 & 80418 \\
\hline - Työkustannus & 43484 & 54534 & 25050 & 34541 & 17699 & 25932 & 14784 & 23621 & 28426 & 33274 & 38164 & 41707 & 42866 & 43611 & 41707 & 41707 & 41707 \\
\hline - Yleiskustannus & 6711 & 7157 & 5284 & 5822 & 4785 & 5221 & 4681 & 5346 & 5682 & 6022 & 6363 & 6087 & 6059 & 6714 & 6030 & 6030 & 603 \\
\hline - Pääomakustannus & 72538 & 73427 & 56040 & 61540 & 50541 & 56040 & 50541 & 57360 & 61122 & 64916 & 68744 & 69951 & 65939 & 72538 & 65939 & 65939 & 6593 \\
\hline $\begin{array}{l}\text { TUOTANTO- } \\
\text { KUSTANNUS }\end{array}$ & 223004 & 249777 & 136802 & 168969 & 106793 & 137530 & 103713 & 140737 & 161031 & 181505 & 202153 & 198400 & 195283 & 223176 & 194094 & 194094 & 19409 \\
\hline + Myyntitulo & 228189 & 253543 & 116216 & 153540 & 78891 & 114094 & 77477 & 125174 & 150704 & 176457 & 202435 & 182551 & 182551 & 228189 & 182551 & 182551 & 18255 \\
\hline + Tuotantotuet & 7656 & 27656 & 23752 & 25054 & 22451 & 7177 & 21116 & 24065 & 24955 & 25853 & 26758 & 22125 & 22125 & 27656 & 22125 & 22125 & 2212 \\
\hline LIIKEVAIHTO & 255845 & 281200 & 139968 & 178594 & 101342 & 131272 & 98593 & 149238 & 175658 & 202310 & 229194 & 204676 & 204676 & 255845 & 204676 & 204676 & 20467 \\
\hline viljelijän palkkavaatim.) & 106486 & 109120 & 49141 & 402 & 31008 & 43105 & 33488 & 56870 & 69610 & 82459 & 95424 & 74999 & 76360 & 106300 & 75401 & 75998 & 7206 \\
\hline $\begin{array}{l}\text { KÄYTTÖKATE } 2 \\
\text { (Viljeljän palkkavaatimus } \\
\text { huomioitu) }\end{array}$ & 86566 & 89200 & 37190 & 50252 & 22043 & 31946 & 25001 & 44002 & 54688 & 65372 & 76295 & 57859 & 57632 & 86380 & 58262 & 58859 & 5492 \\
\hline TYÖANSIO & 44748 & 46139 & -1835 & 10795 & -16363 & -7759 & -13765 & 5070 & 15348 & 25713 & 36175 & 16310 & 20571 & 44559 & 19608 & 20220 & 1618 \\
\hline MAATALOUSTULO & 67922 & 69506 & 18177 & 31861 & 2595 & 12253 & 5193 & 25335 & 36334 & 47426 & 58621 & 38019 & 41086 & 67732 & 40123 & 40735 & 3669 \\
\hline NETTOVOITTO & 24828 & 26219 & -13786 & -4355 & -25329 & -18918 & -22252 & -7799 & 426 & 8626 & 17045 & -829 & 1843 & 24638 & 2468 & 3080 & -95 \\
\hline $\begin{array}{l}\text { KANNATTAVUUS- } \\
\text { KERROIN }\end{array}$ & 1,58 & 1,61 & 0,57 & 0,88 & 0,09 & 0,39 & 0,19 & 0,76 & 1,01 & 1,22 & 1,41 & 0,98 & 1,05 & 1,57 & 1,07 & 1,08 & 0,9 \\
\hline $\begin{array}{l}\text { Tuotantokustannus }(€) 100 \\
\text { perunakiloa kohti }\end{array}$ & 25,93 & 25,76 & 34,51 & 30,80 & 42,65 & 33,71 & 40,69 & 32,64 & 30,07 & 28,27 & 26,90 & 28,83 & 28,46 & 25,95 & 28,37 & 28,28 & 28,85 \\
\hline Erotus & 0,00 & $-0,17$ & 8,58 & 4,87 & 16,72 & 7,78 & 14,76 & 6,71 & 4,14 & 2,34 & 0,98 & 2,90 & 2,53 & 0,02 & 2,44 & 2,35 & 2,92 \\
\hline
\end{tabular}

